\title{
FAMILY FUNCTIONALITY AMONG ISLAND RESIDENTS IN
PROMOTING MASTERY OF QURANIC RECITATION
}

\author{
Mohd Abdul Nasir \\ Abd Abd Latif ${ }^{1+}$ \\ Ahmad Zulfiqar \\ Shah Abdul Hadi ${ }^{2}$ \\ Muhammad Hasbi \\ Abdul Rahman ${ }^{3}$ \\ Muhammad Nadzir \\ Ibrahim $^{4}$
}

\author{
${ }^{1,2,3,4}$ Faculty of Human Sciences, Sultan Idris Education University, Malaysia \\ ${ }^{\prime}$ Email: muhd.nasir@fsk.upsi.edu.my \\ Email:zulfiqar@fsk.upsi.edu.my \\ ${ }^{3}$ Email:muhar@fsk.upsi.edu.my \\ ${ }^{4}$ Email: nadzir@fsk.upsi.edu.my
}

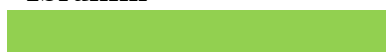

\section{Article History}

Received: 19 August 202 Revised: 1 October 2021

Accepted: 27 October 2021

Published: 15 November 2021

\section{Keywords}

Family functionality

Quranic recitation

Quranic education

Mastery of Al-Quran

Perhentian Island Residents

Terengganu.

\begin{abstract}
This study aimed at identifying family functionality in promoting mastery of al-Quran recitation among the island residents. This Study was conducted involved 70 respondents in Primary School in Perhentian Island (Pulau Perhentian) in Terengganu State of Malaysia. This quantitative study used a questionnaire as the research instrument which focusing on the aspects of functionality support, role, environment and communication. The findings suggest that four aspects in family functionality were at moderately high-level including support $($ mean $=3.55, S D=0.85)$, role $($ mean $=$ 3.72, $S D=0.92)$, environment (mean $=3.47, S D=0.81)$ and communication (mean = 3.73, $S D=0.89)$. Analysis showed no positive relationship was observed between family functionality and mastery of Quranic recitation. This shows that systematic and wisdom planning by the authority are needed so that the existing family functionality can be sustained in a quality way and subsequently help inculcate mastery of al-Quran recitation among the new generation of Perhentian Island residents.
\end{abstract}

Contribution/ Originality: The paper's primary contribution is finding that systematic and wisdom planning by the authority are needed so that the existing family functionality can be sustained in a quality way and subsequently help inculcate mastery of al-Quran recitation among the new generation of Island residents.

\section{INTRODUCTION}

Al-Qur'an education places a clear function on the family in guiding, shaping and nurturing a soul that loves alQur'an in children in order to aid mastery of al-Qur'an learning. A tradition of the Prophet (blessings and peace be upon him) says: "Teach your children three matters; love your Prophet, love the family members and love recitation of the Qur'an" (Al-Tabarani, 1995). This tradition shows clearly that the family must function as early as possible in nurturing the appreciation of al-Quran and ensuring children mastery of Quran recitation skills.

Findings of previous studies show that many students still are incapable of mastering ability to recite al-Quran accordingly. This finding prompted a study on family functionality in helping mastery of al-Qur'an recitation. This study discusses the family practices related to al-Qur'an instruction among children, family management in ensuring children receive al-Quran education and family involvement in improving children's mastery of al-Qur'an. 
The research site was Pulau Perhentian Kecil and Pulau Perhentian Besar, Terengganu. The location was selected based on the need to obtain comprehensive data on how a community involved in the tourism sector totally such as fishermen, chalet operators, tourist boat operators and workers at a tourist centre functioned in ensuring their family members had opportunity to receive al-Qur'an education. The sampling technique was random sampling considering the large location population of respondents and location.

\section{LITERATURE REVIEW}

Family functionality has undergone drastic changes in line with social transformation. The family is not the only institution peacefully imparting protection and socialisation to family members; in fact, the function of family institution is becoming more critical and is facing various social problems. Modernisation of society affects the shaping of new social values related to the family. According to Adi Fahrudin (2014), marital relationships are now regarded as formal relationships as in an organisation patterned on division of tasks and responsibilities. Families have been experiencing these changes such that it is difficult to evaluate which families are fully functioning, dysfunction, healthy, unhealthy, harmonious and chaos.

The phenomenon mentioned above arises as a result of schools of thought holding that development can only happen by absorbing totally modern technology from the West together with adapting the parallel attitudes and value systems (Triandis, 1973). The values associated with developed countries are individualistic (Hofstede, 1994), modern (Inkeles \& Smith, 1974). Nevertheless, these values have encouraged alienation and isolation until they resulted in emotional stress and mental problems in societies in developed countries (Zurina \& Hukil, 2007). Simon (1996) stated that mankind now is beginning to conscious the importance on individuality and too fixated on the economy. In this context, the family now is merely a transit point and no longer a place where children are born and educated.

In the context of al-Qur'an education, the effects of modernisation that led to individualism culture have seen for evaluating family functionality. This is to identify the level of awareness in family members in ensuring other family members are capable of reading al-Quran and appreciating Islam as a way of life. This is because the family plays the main role in building character of family members. Prophet's dignity stated; "Each child is born in a state of fitrah. So, both parents play a role in shaping the child whether as a Jew, Christian or Zoroastrian" (Al-Tabarani, 1995).

The failure to nurture a child from early years can influence the child in appreciating Islamic values. According to Adi Fahrudin (2014) family plays an important role in developing well-being, nurturing and basic education in the family members. This role is not only for certain societies and cultures but is crucial in all cultures in society. This is because the family institution is responsible for the care process, healing, caring and educating children. Amran, Fatimah, and Khadijah (2012) stated that family function is associated with psychological well-being of individuals in the family. He had carried out a pilot study in 2011 on 73 numbers of sample involving parents and children in Peninsular Malaysia. Their results showed there were significant difference was found in wellbeing between parents and children, and significant relationship existed between parenting capability and psychological wellbeing.

Among the basics of al-Qur'an education is the family functionality in guiding, shaping and nurturing love for al-Qur'an in children. This is in line with the command from Allah in the Qur'an that every parent should guard themselves and their families from hellfire. As commanded by Allah;

O ye who believe, protect yourself and your family from hellfire (Surah al-Tahrim: 6).

Based on the preceding discussion, this work presents the findings of a study related to family function in nurturing interest in al-Quran and its impact on mastery of al-Qur'an recitation. This is because previous studies showed that extent of mastery and appreciation of al-Qur'an is getting worrying as shown in studies by Mohd Faisal, Zawawi, and Rahimi (2008) and Azarudin, Mat, Nazuki, and Yaakub (2011). 
The island community is the community focused in this study. They are a people isolated in terms of location and infrastructure from what is usually enjoyed by the mainland community. The community of the islands and coastal regions have a lifestyle much different from that of the mainland communities. Their lifestyle are often related to natural resources such as fishery resources and income from presence of tourists from within and outside the country. Their pattern of acquisition and expenditure are also not uniform and often related to wealth gaps among themselves from the viewpoint of socio-economy and seasonal influence. The island communities are often constrained by poverty and economically backward even though they possess invaluable natural resources (Nanthakumar \& Thirunaukarasu, 2005).

In the context of a rural community in the tourist islands being studied, two questions have been raised, whether they are marginalised by development or whether they marginalise themselves from the development process. Hence this marginalisation is seen not only from the physical aspect but encompasses the economic, social, and also political that is often the core discussion in the context of development and change in a local community (Yahaya, 2006).

Considering that most studies put forward related to al-Qur'an education only focused on mainland communities such as studies by Salina (2006); Mohd Faisal et al. (2008); Siti-Fatimah (2005); Misnan (2005); Mohd, Zulkifli, and Saidi (2007) and Azarudin et al. (2011) therefore studies related to island communities with different way of life as discussed is needed to be focused. This is important in order to see the fundamentals of al-Qur'an education among them by looking initially at family functionality as the basis in educating children. Proper care and nurturance as well as enough attention and love for children will shape their future in life. High or low academic achievement depends on whether a person has positive or negative self-concept in learning (Ishak-Mad, 2004) where inculcation of self-concept begins with parental involvement in the education process (Rohaty, 2003).

Selection of the island is significant because of several factors; specifically, the majority of the island population are Muslims and most of them have a certain education level and are involved in the tourism sector. According to Yahaya (2006) Perhentian Island is host to 1,393 residents. The majority of islanders are Malays who are Muslims (98.8\%). 58.4\% are indigenous residents of the island while $38.7 \%$ are migrants from outside the island but citizens of Malaysia and only $2.9 \%$ are non-citizen migrants. A small minority (four families) of local residents have married foreigners and live on the island but occasionally return to their original homeland.

This study found that $76.9 \%$ of 173 heads of household interviewed have received a certain level of education while $16.2 \%$ did not. Originally, almost all heads of household were fishermen, but today, with tourism activities accelerating, it was found that 39.9\% (69 heads of household) are involved in the tourism sector as chalet operators $(10.4 \%)$, tourist boat operators $(14.5 \%)$, and work in tourist centres as assistants or guides (15\%). Today, the traditional sector is operated by less than $20 \%$ of the island population (Yahaya, 2006).

\section{METHODOLOGY}

This research uses a quantitative approach. For this purpose, it uses a survey questionnaire as main instrument. This instrument is used to explain data related to family functionality through statistics. The instrument is divided into two parts namely respondent demographics and aspects of family functionality such as role, environment, and communication. A total of 31 items are presented.

The respondents consisted of from three, four, five and six of Pulau Perhentian National Primary School students. This school is the only primary school on the island. The research data were analysed using IBM SPSS Statistics for Windows, Version 22.0. to identify mean and standard deviation to answer the research questions. The research data were analysed descriptively through frequency, percentage, mean and standard deviation. Data were also analysed by $t$-test and One Way Analysis of Variance (One-way ANOVA) to analyse the differences between variables. At the same time, Pearson correlation analysis was used to analyse the relationship between 
constructs used. The findings play a role in providing data to identify strengths and weaknesses of family functionality in ensuring children get instruction in al-Qur'an.

\section{FINDINGS}

The following are the findings of the research based on the analysis undertaken.

\subsection{Sample}

The sample profile in this study refers to four main variables of the respondents involved, namely demographics of gender, number of siblings, father's education level, mother's education level among residents of Perhentian Island.

\subsection{Demographic Profile of Sample}

The sample distribution by gender, number of siblings, father's education level and mother's education level given in the following tables:

Table-1. Demographic profile according to gender.

\begin{tabular}{c|c|c}
\hline Gender & $\mathbf{N}$ & $\mathbf{\%}$ \\
\hline Male & 30 & 42.9 \\
\hline Female & 40 & 57.1 \\
\hline Total & 70 & 100 \\
\hline
\end{tabular}

Based on Table 1, some 70 respondents were involved in the study. Of this total, 30 (42.9\%) were male students and $40(57.1 \%)$ were female. This showed that the number of female respondents exceeded the number of males in the study sample.

Table-2. Sample profile according to number of siblings.

\begin{tabular}{c|c|c}
\hline Frequency & $\mathbf{N}$ & $\mathbf{\%}$ \\
\hline 1-3 siblings & 37 & 52.9 \\
\hline 4-7 siblings & 30 & 42.9 \\
\hline 8-11 siblings & 3 & 4.3 \\
\hline Total & 70 & 100 \\
\hline
\end{tabular}

Table 2 shows the breakdown of sample according to number of siblings. Some 37 respondents (52.9\%) have 13 siblings, $30(42.9 \%)$ have $4-7$ siblings, while 3 respondents (4.3\%) have $8-11$ siblings.

Table-3. Sample profile by father's education.

\begin{tabular}{c|c|c}
\hline Level & $\mathbf{N}$ & \% \\
\hline No qualification & 11 & 15.7 \\
\hline SPM & 46 & 65.7 \\
\hline STAM & 2 & 2.9 \\
\hline STPM & 1 & 1.4 \\
\hline Degree & 10 & 14.3 \\
\hline TOTAL & 70 & 100 \\
\hline
\end{tabular}

Table 3 shows the distribution of sample according to father's education level. Some 11 respondents (15.7\%) stated no qualification for father's education level, at SPM level the figure was 46 people (65.7\%), for STAM level the number was 2 people $(2.9 \%)$, while for STPM level it was only one respondent $(1.4 \%)$, and for degree level 10 respondents $(14.3 \%)$ stated that their fathers had degree qualification 
Table-4. Respondent profile by Mother's Education Level.

\begin{tabular}{c|c|c}
\hline Level & $\mathbf{N}$ & \% \\
\hline No formal qualification & 7 & 10.0 \\
\hline SPM & 49 & 70.0 \\
\hline STAM & 3 & 4.3 \\
\hline STPM & 0 & 0.00 \\
\hline DEGREE & 11 & 15.7 \\
\hline Total & 70 & 100 \\
\hline
\end{tabular}

Table 4 shows the breakdown of sample by mother's education level. Some seven (7) respondents (10.0\%) stated that their mothers had no formal educational qualification, some 49 (70.0\%) have mothers who attained SPM, some 3 people (4.3\%) have mothers with STAM level qualification, while 11 respondents (15.7\%) stated their mothers hold degrees.

\subsection{Completion of Al Quran}

The following Table 5 shows the percentage of those having completed al-Quran.

Table-5. Percentage of sample having completed al- Quran.

\begin{tabular}{c|c|c}
\hline Level & $\mathbf{N}$ & $\mathbf{\%}$ \\
\hline Have completed & 19 & 27.1 \\
\hline Never completed & 51 & 72.9 \\
\hline Total & 70 & 100 \\
\hline
\end{tabular}

Table 5 displays the breakdown of sample according to completion of al-Quran recitation. Some 19 respondents $(27.1 \%)$ have completed al-Quran, while the remaining 51 people (72.9\%) have not completed al-Quran.

\subsection{Ability to read al-Quran}

Table 6 shows the sample breakdown according to ability to read al-Quran.

Table-6. Ability to read al-Quran

\begin{tabular}{c|c|c}
\hline Level & $\mathbf{N}$ & $\mathbf{\%}$ \\
\hline Able to read & 51 & 72.9 \\
\hline Unable to read & 19 & 27.1 \\
\hline Total & 70 & 100 \\
\hline
\end{tabular}

Table 6 shows the distribution of sample based on ability to read al-Quran. Some 51 respondents (72.9\%) can read al-Quran, while the rest numbering 19 respondents (27.1\%) do not know how to read al-Quran.

\subsection{Frequency of al-Quran Recitation}

The following data refer to frequency of reading al-Quran at home. It is categorised into three choices, frequent, sometimes and never read al-Quran. The following Table 7 shows the numbers of frequency resulting from data collection through the questionnaire.

Table-7. Frequency of reading al-Quran

\begin{tabular}{c|c|c}
\hline Frequency & N & \% \\
\hline Frequent & 15 & 21.4 \\
\hline Sometimes & 47 & 67.1 \\
\hline Never & 8 & 11.4 \\
\hline Total & 70 & 100 \\
\hline
\end{tabular}


Table 7 shows that 47 respondents recite al-Quran occasionally (representing $67.1 \%$ ), followed by respondents who often recite al-Quran numbering 15 people (21.4\%). Only $8(11.4 \%)$ respondents said they have never read alQuran. This clearly shows that respondents do not often read al-Quran in their routine.

\section{DESCRIPTIVE ANALYSIS}

Descriptive analysis was carried out to identify the level of respondents' family functionality. The findings of analysis are as follows:

\subsection{Family Functionality}

This section will clarify the findings of analysis in descriptive form for the items in the instrument according to family functionality namely support (6 items), role (6 items), environment (6 items) and communication (6 items). The details of analysis of findings are as follows:

\subsection{Support Aspect}

Table 8 displays the results for support aspect in family functionality.

Table-8. Aspect of support in family functionality.

\begin{tabular}{|c|c|c|c|c|c|c|c|c|}
\hline \multirow[t]{2}{*}{ Item Code } & \multicolumn{5}{|c|}{ Frequency and Percentage $(\mathrm{N}=120)$} & \multirow[t]{2}{*}{ Mean } & \multirow[t]{2}{*}{ SD } & \multirow[t]{2}{*}{ Int } \\
\hline & SD & D & $\mathbf{N}$ & A & SA & & & \\
\hline \multirow{2}{*}{$\begin{array}{l}\text { My siblings encourage me } \\
\text { to recite al-Quran }\end{array}$} & 25 & 8 & 15 & 5 & 17 & 2.73 & 1.59 & $\mathrm{ML}$ \\
\hline & $(35.7)$ & $(11.4)$ & $(21.4)$ & $(7.1)$ & $(24.3)$ & & & \\
\hline \multirow{2}{*}{$\begin{array}{l}\text { My siblings guide me } \\
\text { when i read al-Quran }\end{array}$} & 16 & 12 & 20 & 6 & 16 & 2.91 & 1.45 & ML \\
\hline & $(22.9)$ & $(17.1)$ & $(28.6)$ & $(8.6)$ & $(22.9)$ & & & \\
\hline \multirow{3}{*}{$\begin{array}{l}\text { My parents always } \\
\text { encourage me to read al- } \\
\text { Quran }\end{array}$} & 5 & 3 & 6 & 15 & 41 & 4.20 & 1.21 & $\mathrm{H}$ \\
\hline & $(7.1)$ & $(4.3)$ & $(8.6)$ & $(21.4)$ & $(58.6)$ & & & \\
\hline & & & & & & & & \\
\hline \multirow{2}{*}{$\begin{array}{l}\text { My family provide al-Quran } \\
\text { for me to recite }\end{array}$} & 5 & 4 & 5 & 19 & 37 & 4.13 & 1.21 & $\mathrm{H}$ \\
\hline & $(7.1)$ & $(5.7)$ & $(7.1)$ & $(27.1)$ & $(52.9)$ & & & \\
\hline \multirow{4}{*}{$\begin{array}{l}\text { My parents prepare a } \\
\text { teacher for me and my } \\
\text { siblings to teach } \\
\text { al-Quran }\end{array}$} & 10 & 6 & 15 & 15 & 24 & 3.53 & 1.41 & $\mathrm{MH}$ \\
\hline & $(14.3)$ & $(8.6)$ & $(21.4)$ & $(21.4)$ & $(34.3)$ & & & \\
\hline & & & & & & & & \\
\hline & & & & & & & & \\
\hline \multirow{4}{*}{$\begin{array}{l}\text { My parents give instruction } \\
\text { for me to } \\
\text { perfect my al-Quran reading }\end{array}$} & 8 & 2 & 17 & 8 & 35 & 3.86 & 1.37 & $\mathrm{MH}$ \\
\hline & $(11.4)$ & $(2.9)$ & $(24.3)$ & $(11.4)$ & $(50.0)$ & & & \\
\hline & & & & & & & & \\
\hline & & & & & & & & \\
\hline Overall & & & & & & 3.55 & 0.85 & $\mathrm{MH}$ \\
\hline \begin{tabular}{l|l} 
L & Low \\
\end{tabular} & ely Low & A & Average & $\mathrm{MH}$ & Moder & ly High & $\mathrm{H}$ & High \\
\hline
\end{tabular}

Findings as shown in Table 8 show the distribution of frequency score, percentage, mean and standard deviation for the aspect support in family functionality. On the whole, the findings on mastery are at the moderately high level $($ mean $=3.55, S D=0.85)$. Two items namely parents give encouragement in reading al-Quran (mean $=$ $4.20, S D=1.21)$ and the family prepares al-Quran for children to read it (mean $=4.13, S D=1.21)$ were at high level while two items namely parents prepare teacher to teach al-Quran (mean $=3.53, S D=1.41$ ) and parents give guidance in perfecting al-Quran reading (mean $=3.86, S D=1.37$ ) were at the moderately high level and other items are at the moderately low level.

\subsection{Family Functionality from the Role Aspect}

Table 9 displays the results for the role aspect of family functionality. 
Table-9. Aspect of role and family functionality.

\begin{tabular}{|c|c|c|c|c|c|c|c|c|}
\hline \multirow[t]{2}{*}{ Item Code } & \multicolumn{5}{|c|}{ Frequency and Percentage $(\mathrm{N}=120)$} & \multirow[t]{2}{*}{ Mean } & \multirow[t]{2}{*}{ SD } & \multirow[t]{2}{*}{ Int } \\
\hline & SD & D & $\mathbf{N}$ & A & SA & & & \\
\hline \multirow{3}{*}{$\begin{array}{l}\text { My parents is aware with the } \\
\text { quality of my al-Quran reading }\end{array}$} & 5 & 5 & 16 & 15 & 29 & 3.83 & 1.25 & $\mathrm{MH}$ \\
\hline & $(7.1)$ & $(7.1)$ & $(22.9)$ & $(21.4)$ & $(41.4)$ & & & \\
\hline & & & & & & & & \\
\hline \multirow{3}{*}{$\begin{array}{l}\text { My parents send me to al-Qur'an } \\
\text { Reading class }\end{array}$} & 10 & 8 & 15 & 9 & 28 & 3.53 & 1.47 & $\mathrm{MH}$ \\
\hline & $(14.3)$ & $(11.4)$ & $(21.4)$ & $(12.9)$ & $(40.0)$ & & & \\
\hline & & & & & & & & \\
\hline \multirow{3}{*}{$\begin{array}{l}\text { My parents remind me to read } \\
\text { al-Qur'an }\end{array}$} & 3 & 4 & 12 & 16 & 35 & 4.09 & 1.13 & $\mathrm{H}$ \\
\hline & $(4.3)$ & $(5.7)$ & $(17.1)$ & $(22.9)$ & $(50.0)$ & & & \\
\hline & & & & & & & & \\
\hline \multirow{3}{*}{$\begin{array}{l}\text { My parents make sure that i read } \\
\text { al-Qur'an everyday }\end{array}$} & 7 & 4 & 12 & 11 & 36 & 3.93 & 1.35 & $\mathrm{MH}$ \\
\hline & $(10.0)$ & $(5.7)$ & 17.1 & 15.7 & 51.4 & & & \\
\hline & & & & & & & & \\
\hline \multirow{3}{*}{$\begin{array}{l}\text { My parents always recite al- } \\
\text { Qur'an }\end{array}$} & 5 & 1 & 15 & 16 & 33 & 4.01 & 1.18 & $\mathrm{H}$ \\
\hline & $(7.10)$ & $(1.4)$ & $(21.4)$ & $(22.9)$ & $(47.1)$ & & & \\
\hline & & & & & & & & \\
\hline \multirow{3}{*}{$\begin{array}{l}\text { My parents fix a schedule for me } \\
\text { to read al-Qur'an }\end{array}$} & 14 & 10 & 22 & 13 & 11 & 2.96 & 1.33 & VL \\
\hline & $(20.0)$ & 14.3 & 31.4 & $(18.6)$ & $(15.7)$ & & & \\
\hline & & & & & & & & \\
\hline Overall $\sim$ & & & & & & 3.72 & 0.92 & $\mathrm{MH}$ \\
\hline Moderate & Low & $\mathrm{A}$ & Average & $\mathrm{MH}$ & Moder: & ely High & $\mathrm{H}$ & High \\
\hline
\end{tabular}

Table 9 displays the results for the role aspect in family functionality. The overall mean value was at moderately high level of $3.72(S D=0.92)$. On the whole, two items were at high level namely the item parents remind to read al-Quran $($ mean $=4.09, S D=1.13)$ and parents always recite al-Quran $($ mean $=4.01, S D=1.18)$. The other items are at the moderately high level with lowest mean scores for the item parents send children to recitation class for learning al-Quran (mean $=3.53, S D=1.47)$ and the item parents fix a time table or schedule for reading al-Qur'an $($ mean $=3.72, S D .=0.92)$.

\subsection{Family functionality from the Environment aspect}

Table 10 displays the results for aspect of Environment in Family Functionality.

Table-10. Aspect of environment in family functionality.

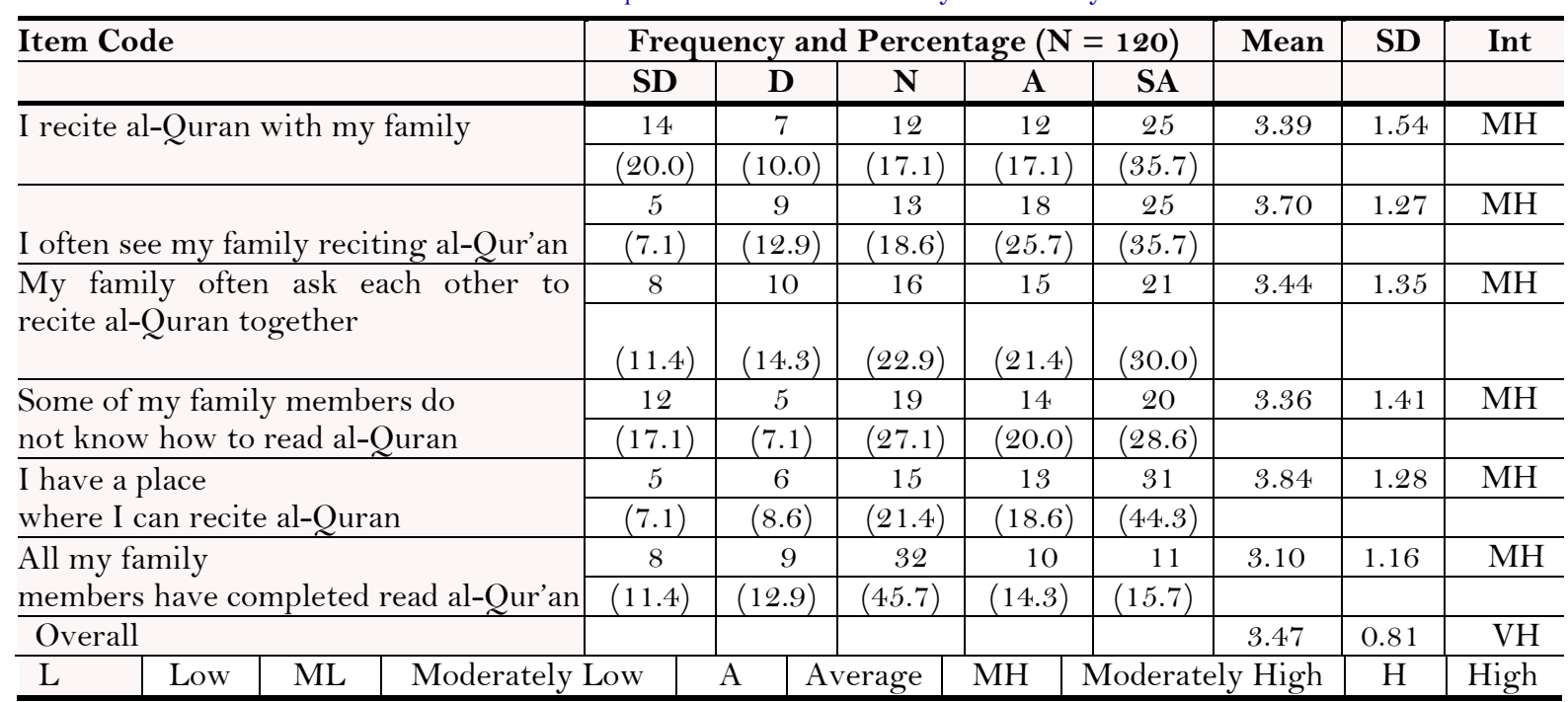


Table 10 shows the mean values for the aspect of environment; the table shows that environment aspect is at moderately high level $($ mean $=3.47, S D=0.81)$. Overall, all six items are at the moderately high level, with detailed results being: the statement reading the Quran with the family (mean $=3.39, S D=1.54$ ), often seeing the family reciting $($ mean $=3.70, S D=1.27)$, family often encourage each other to recite al-Quran together $($ mean $=3.44, S D$ $=1.35$ ), family members found not knowing how to recite al-Qur'an (mean $=3.36, S D=1.41$ ), have a place to study al-Qur'an (mean $=3.84, S D=1.28)$ and all family members have completed al-Quran $($ mean $=3.10, S D=$ $1.16)$.

\subsection{Family Functionality from Communication Aspect}

Table 11 displays the results for communication aspect in family functionality.

Table-11. Communication aspect in family functionality.

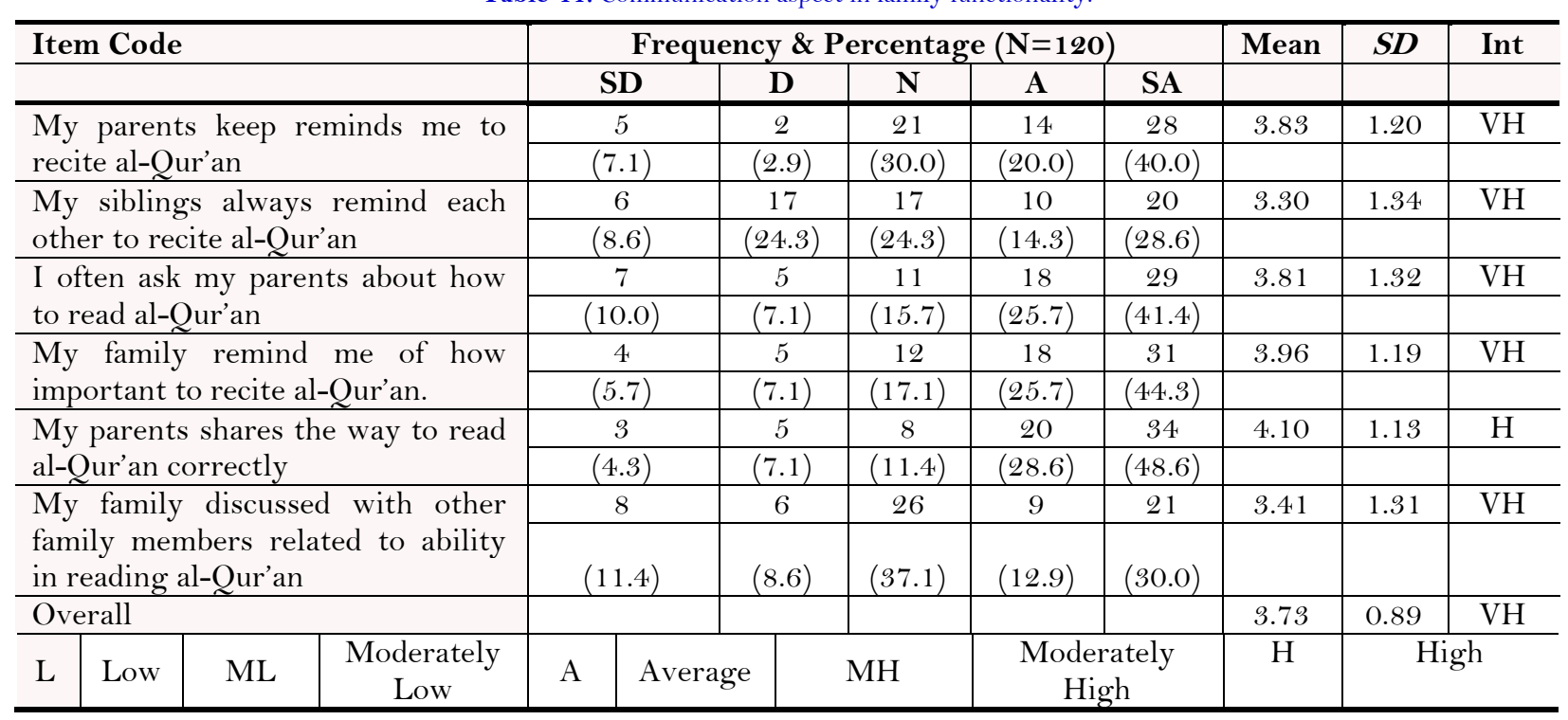

The data displayed in Table 11 shows that the overall mean for the communication aspect of family functionality is at moderately high $(\mathrm{MH})$ level (mean $=3.73, S D=0.89$ ). On the whole, five items were at moderately high level with the highest score obtained by the item family reminds on the importance of reciting alQur'an (mean $=3.96, S D=1.19$ ) whereas the lowest score was for the item siblings often remind each other to recite al-Quran $($ mean $=3.30, S D=1.34)$. The item obtaining a high-level mean was the family shares the best way to read al-Qur'an correctly (mean $=4.10, S D=1.13$ ). On the whole aspect of family functionality among the island community is at moderately high level from the support aspect (mean $=3.55, S D=0.85)$, role aspect $($ mean $=3.72$, $S D=0.92)$, environment aspect $($ mean $=3.47, S D=0.81)$ and communication aspect $($ mean $=3.73, S D=0.89)$.

\section{ANALYSIS OF DIFFERENCES}

In order to identify differences in various dependent variables, the collected data were analysed inferentially. Two approaches to analysis were carried out, namely $t$-test and One-way ANOVA.

\subsection{Differences in Mean Score for Family Functionality Based on Gender}

Table 12 displays the results for $t$-test for differences in family functionality aspects by gender. 
Table-12. $t$-Test for differences in family functionality aspects by gender.

\begin{tabular}{|c|c|c|c|c|c|}
\hline Item & Gender & $\mathbf{N}$ & Mean & $S D$ & $p$ Value \\
\hline \multirow[t]{2}{*}{ Support } & Male & 30 & 3.61 & 0.89 & \multirow[b]{2}{*}{0.49} \\
\hline & Female & 40 & 3.70 & 0.80 & \\
\hline \multirow[t]{2}{*}{ Role } & Male & 30 & 3.62 & 0.92 & \multirow[b]{2}{*}{0.84} \\
\hline & Female & 40 & 3.79 & 0.92 & \\
\hline \multirow[t]{2}{*}{ Environment } & Male & 30 & 3.35 & 0.78 & \multirow[b]{2}{*}{0.56} \\
\hline & Female & 40 & 3.56 & 0.83 & \\
\hline \multirow[t]{2}{*}{ Communication } & Male & 30 & 3.56 & 0.85 & \multirow[b]{2}{*}{0.82} \\
\hline & Female & 40 & 3.86 & 0.90 & \\
\hline \multirow{2}{*}{$\begin{array}{l}\text { Family } \\
\text { Functionality }\end{array}$} & Male & 30 & 3.47 & 0.75 & \multirow[b]{2}{*}{0.86} \\
\hline & Female & 40 & 3.73 & 0.72 & \\
\hline
\end{tabular}

Analysis of the $t$-test as in Table 12 on the whole shows that no significant difference found for the four aspects of family functionality between gender from the aspects of support $(p=0.49, p>0.05)$, role $(p=0.84, p>0.05)$ environment $(p=0.56, p>0.05)$ and communication $(p=0.82, p>0.05)$. This shows that family function for this sample is the same and does not differ by gender.

6.2. Differences in Mean Score for Family Functionality Based on Number of Siblings

Table 13 displays results for One Way ANOVA for differences based on number of siblings for the sample.

Table-13. One Way ANOVA for differences.

\begin{tabular}{c|c|c|c|c|c}
\hline & JKD & Df & MKD & $\boldsymbol{F}$ & Sig. $\boldsymbol{p}$ \\
\hline Between groups & 3.992 & 2 & 3.039 & 34.871 & $0.000^{*}$ \\
\hline Within group & 34.212 & 67 & 0.087 & & \\
\hline Total & 38.204 & & & & \\
Note: *Significant at the level $p<0.05$.
\end{tabular}

Findings from the one-way analysis of variance as displayed in Table 13 show that a significant difference $(p=$ 0.000, $p<0.05$ ) exists for family functionality based on number of siblings. To identify the difference in score between different numbers of siblings, a post-hoc Scheffe test was conducted. The results are displayed in Table 14:

Table-14. Post-hoc Scheffe test for differences.

\begin{tabular}{c|c|c|c|c|c}
\hline Number & $\mathbf{N}$ & Mean & $\mathbf{1 - 3}$ siblings & 4-7 siblings & 8-1 1 siblings \\
\hline 1-3 siblings & 37 & 3.40 & & $-0.456^{*}$ & -0.642 \\
\hline $4-7$ siblings & 30 & 3.86 & $0.456^{*}$ & & -0.186 \\
\hline 8-11 siblings & 3 & 4.04 & 0.642 & 0.186 & \\
\hline
\end{tabular}

Based on the post-hoc Scheffe test carried out to identify the differences in score between different sibling groups as in Table 14, the findings suggest that the mean score was significant for two groups namely 1-3 siblings $(p=0.040, p<0.050)$ and 4-7 siblings $(p=0.040, p<0.050)$. The mean score for 8-11 siblings $($ mean $=4.04)$ with the aspect of family functionality is higher compared with the mean score for 1-3 siblings (mean $=3.40$ ), and 4-7 siblings $($ mean $=3.86$ ), while the mean score for family functionality for number of siblings did not show any significant difference $(p=0.332, p>0.05)$. This finding shows that the higher number of siblings the higher the family functionality occoured.

\subsection{Difference in Mean Score for Aspects of Family Functionality Based on Mother's Education}

Table 15 gives the results for One-way ANOVA for difference in mean scores based on mother's education level. 
Table-15. One-way ANOVA for difference.

\begin{tabular}{c|c|c|c|c}
\hline & Sum of Squares & Mean of Squares & $\boldsymbol{F}$ & Sig. $\boldsymbol{p}$ \\
\hline Between Groups & 1.008 & 0.336 & 0.596 & 0.620 \\
\hline Within Groups & 37.196 & 0.564 & & \\
\hline Total & 38.204 & & & \\
\hline
\end{tabular}

The variance analysis finding as in Table 15 show that a significant difference exists $(p=0.620, p<0.05)$ for the aspect of family functionality based on mother's education level. To identify differences in score between different education levels, a post-hoc Scheffe test was conducted. Results for this test are displayed in Table 16.

Table-16. Post-hoc scheffe test for difference in family functionality according to mother's education level.

\begin{tabular}{c|c|c|c|c|c|c}
\hline Level of Education & $\mathbf{N}$ & Mean & No Qualification & SPM & STAM & Degree \\
\hline No qualification & 7 & 3.64 & & 0.07 & -0.46 & -0.08 \\
\hline SPM & 49 & 3.56 & -0.07 & & -0.54 & -0.16 \\
\hline STAM & 3 & 4.11 & 0.46 & 0.54 & & 0.38 \\
\hline Degree & 11 & 3.73 & 0.08 & 0.16 & -0.38 & \\
\hline
\end{tabular}

Based on the post-hoc Scheffe test carried out to identify the differences in mean score between mother's education levels as in Table 16, on the whole no significant difference exists for the four aspects of family functionality and mother's education level. The highest mean score was for the level STAM $($ mean $=4.11, p=$ 0.84), followed by degree level (mean = 3.73), no qualification (mean = 3.64) and SPM level $($ mean $=3.56)$. This shows that the mothers in the community play an active role regardless of their academic qualification.

\subsection{Differences in Mean Score of Family Functionality Based on Completion of Al-Quran}

Table 17 shows the results for the $t$-test for difference in family functionality based on completion of al-Quran.

Table-17. The $t$-Test for difference in family functionality based on completion of al-Quran.

\begin{tabular}{c|c|c|c|c|c}
\hline Variable & Level & N & Mean & SD. & $\boldsymbol{p}$ Value \\
\hline Support & Have completed & 19 & 3.72 & 0.88 & 0.524 \\
\hline & Never completed & 51 & 3.49 & 0.84 & \\
\hline & Have completed & 19 & 3.99 & 1.02 & 0.558 \\
\hline Role & Never completed & 51 & 3.62 & 0.86 & \\
\hline Environment & Have completed & 19 & 3.68 & 0.90 & 0.419 \\
\hline & Never completed & 51 & 3.39 & 0.77 & \\
\hline Communication & Have completed & 19 & 3.94 & 1.10 & 0.112 \\
\hline & Never completed & 51 & 3.65 & 0.80 & \\
\hline Family Functionality & Have completed & 19 & 3.83 & 0.92 & 0.082 \\
\hline & Never & 51 & 3.54 & 0.65 & \\
\hline & & & & &
\end{tabular}

Analysis of $t$-test as in Table 17 shows that no significant difference exists for aspects of family functionality based on completion of al-Quran by respondents. Analysis shows that the aspect of support $(p=0.524, p>0.05)$ role $(p=0.558, p>0.05)$, environment $(p=0.419, p>0.05)$, and communication $(p=0.112, p>0.05)$ were not significant in relation to completion of al-Quran. Hence, on the whole no significant difference exists $(p=0.082, p>$ 0.05 ) for family functionality based on completion of al-Quran by respondents. This shows that the quality of family functionality at this level must be emphasised so that the functionality gives positive impact. 


\subsection{Difference in Mean Score for Aspects of Family Functionality Based on Ability to Read al-Quran (t-test)}

Table 18 displays the $t$-test results for differences in aspects of family functionality according their ability to recite al-Quran.

Table-18. The $t$-Test for Difference in Family functionality aspects based on ability to read al-Quran

\begin{tabular}{|c|c|c|c|c|c|}
\hline Variable & Level & $\mathbf{N}$ & Mean & $S D$ & $p$ Value \\
\hline \multirow[t]{2}{*}{ Support } & Able & 51 & 3.67 & 0.77 & \multirow{2}{*}{0.112} \\
\hline & Unable & 19 & 3.25 & 1.01 & \\
\hline \multirow[t]{2}{*}{ Role } & Able & 51 & 3.79 & 0.87 & \multirow{2}{*}{0.334} \\
\hline & Unable & 19 & 3.53 & 1.03 & \\
\hline \multirow[t]{2}{*}{ Environment } & Able & 51 & 3.54 & 0.80 & \multirow{2}{*}{0.924} \\
\hline & Unable & 19 & 3.27 & 0.83 & \\
\hline \multirow[t]{2}{*}{ Communication } & Able & 51 & 3.75 & 0.95 & \multirow{2}{*}{0.262} \\
\hline & Unable & 19 & 3.68 & 0.73 & \\
\hline \multirow[t]{2}{*}{ Family Functionality } & Able & 51 & 3.69 & 0.74 & \multirow{2}{*}{0.702} \\
\hline & Unable & 19 & 3.43 & 0.71 & \\
\hline
\end{tabular}

Analysis of the $t$-test as in Table 18 shows that no significant difference exists for aspects of family functionality based on ability of respondents to read al Quran from the aspect of support $(p=0.112, p>0.05)$ role $(p$ $=0.334, p>0.05)$, environment $(p=0.924, p>0.05)$, and communication $(p=0.262, p>0.05)$. Hence, overall, there is no significant differences $(p=0.702, p>0.05)$ in family functionality based on respondent ability to read alQuran. This shows that quality of family functionality at this level must be emphasised so that the functionality gives positive impact.

6.6. Differences in Mean Score for Aspect of Family Functionality Based on Frequency of Recitation Al-Quran (ANOVA)

Table 19 gives the results for One-Way ANOVA for differences based on frequency of al-Quran's recitation.

Table-19. One-Way ANOVA for Differences based on frequency of al-Quran reading.

\begin{tabular}{c|c|c|c|c|c}
\hline & Sum of Squares & Df & Mean of Squares & $\boldsymbol{F}$ & Sig. $\boldsymbol{p}$ \\
\hline Between Groups & 4.055 & 2 & 2.028 & 3.97 & $0.024^{*}$ \\
\hline Within Groups & 34.149 & 67 & 0.510 & & \\
\hline Total & 38.204 & 69 & & & \\
\hline
\end{tabular}

Results of one-way Analysis of Variance as in Table 19 show that significant difference exists $(p=0.024, p<$ 0.05) for the aspect family functionality based on frequency of al Quran recitation among respondents. To identify the difference in scores between different education levels, a post-hoc Scheffe test was carried out. The results of the test are displayed in the following Table 20:

Table-20. Post-hoc Scheffe test Results for Frequency of al-Quran reading.

\begin{tabular}{c|c|c|c|c|c}
\hline Level & N & Mean & Frequent & Sometimes & Never \\
\hline Frequent & 8 & 4.04 & & 0.48 & $0.807^{*}$ \\
\hline Sometimes & 47 & 3.55 & -0.48 & & 0.321 \\
\hline Never & 15 & 3.23 & $-0.807^{*}$ & -0.321 & \\
\hline
\end{tabular}

Based on the post-hoc Scheffe test carried out to identify the difference in mean scores of family functionality based on frequency of reading al Quran, significant difference was found at the level of frequent and never $(p=$ 0.042, $p<0.05)$. The highest mean score was at the level of frequent (mean $=4.04$ ), followed by sometimes/occasionally (mean $=3.55)$, and never (mean =3.23). This suggests that family functionality is at good level in helping family members which regularly recite al-Qur'an. 


\section{ANALYSIS OF RELATIONSHIP}

Inferential data analysis was carried out to identify the relationship between two main constructs used in this research namely family functionality and completion of al-Quran among respondents. Pearson correlation analysis was done in analysing this relationship.

\subsection{Correlation between Family Functionality and Completion of Al-Quran}

Table 21 gives the results for correlation between family functionality and ability to read al- Quran.

Table-21. Correlation between family functionality and ability to complete al Quran.

\begin{tabular}{l|c|c}
\hline Family Functionality & $\boldsymbol{R}$ & Sig. $\boldsymbol{p}$ \\
\hline Family support * Completion of al-Quran & -1.21 & 0.319 \\
\hline Family role * Completion of al-Quran & -1.78 & 0.140 \\
\hline Family environment *Completion of al-Quran & -1.60 & 0.185 \\
\hline Family communication*Completion of al- Quran & -1.45 & 0.229 \\
\hline Overall & -1.70 & 0.141 \\
\hline
\end{tabular}

Results of Pearson correlation analysis to determine the relationship between aspects of family functionality with the construct completion of al Quran are displayed in Table 21 shows no strong relationship exists between the four aspects of family functionality namely support $(r=-1.21, p<0.01)$, role $(r=-1.78 p<0.01)$, environment $(r=-1.60, p<0.01)$ and communication $(r=-1.45, p<0.01)$ with completion of al Quran among the respondents. On the whole, the relationship between family functionality and completion of al Quran is weak $(r=-1.70, p<$ $0.01)$.

\subsection{Correlation between Family Functionality and Ability to Read Al Quran}

Table 22 displays the correlation between family functionality and ability to read al Quran

Table-22. Correlation between family functionality and ability to read al-Quran.

\begin{tabular}{l|c|c}
\hline Family Functionality & $\boldsymbol{R}$ & Sig. $\boldsymbol{p}$ \\
\hline Family support* ability to read al Quran & -0.219 & 0.069 \\
\hline Family role*ability to read al Quran & -0.126 & 0.299 \\
\hline Family environment*ability to read al-Qur'an & -0.150 & 0.215 \\
\hline Family communication*ability to read al-Qur'an & -0.035 & 0.771 \\
\hline OVERALL & -1.54 & 0.204 \\
\hline
\end{tabular}

Findings of Pearson correlation analysis to identify the relationship between aspects of family functionality and the ability to read al-Quran are given in Table 22. The findings show that no significant relationship exists between the four aspects of family functionality namely support $(r=-0.219, p \geq 0.01)$, role $(r=-0.126 p \geq 0.01)$, environment $(r=-0.150, p \geq 0.01)$ and communication $(r=-0.035, p \geq 0.01)$ with the ability to recite al-Quran among the respondents. On the whole, the relationship between the two constructs is not significant $(r=-0.154, p \geq 0.01)$

\subsection{Correlation between Family Functionality and Frequency of Reading Al Quran}

Table 23 displays the correlation between family functionality and ability to read al-Quran.

Results of Pearson correlation analysis to identify the relationship between aspects of family functionality with the construct frequency of reading al-Quran are displayed in Table 23; it is shown that a strong relationship exists between two aspects of family functionality namely support $\left(r=-0.354^{* *}, p<0.01\right)$ and environment $\left(r=-0.339^{* *}\right.$, $p<0.01)$. Meanwhile, two aspects namely role $(r=-0.210 p<0.01)$, and communication $(r=-0.205, p<0.01)$ have 
moderately strong relationship based on ability to read al-Quran. Overall, the relationship between the two constructs is strong $\left(r=-0.322^{*} *, p<0.01\right)$.

Table-23. Correlation between family functionality and ability to read al-Quran.

\begin{tabular}{l|c|c}
\hline Family functionality & $\boldsymbol{R}$ & Sig. $\boldsymbol{p}$ \\
\hline Family support * frequency of reciting al Quran & $-0.354^{* *}$ & 0.003 \\
\hline Family role *frequency of reciting al-Quran & -0.210 & 0.081 \\
\hline Family environment* frequency of reciting al-Quran & $-0.339^{* *}$ & 0.004 \\
\hline Family communication* frequency of reciting al-Quran & -0.205 & 0.089 \\
\hline Overall & $-0.322^{* *}$ & 0.007 \\
\hline
\end{tabular}

Correlation analysis in general shows that no strong relationship exists between family functionality and completion of al-Qur'an $(r=-1.70, p<0.01)$ and ability to recite al-Qur'an $(r=-0.154, p<0$.01). Nevertheless, correlation between family functionality and frequency of Quranic recitation shows a strong relationship $(r$ $\left.0.322^{* *}, p<0.01\right)$. This finding shows that the island community has awareness of ensuring their family members recite al-Qur'an. Nevertheless, they face obstacles in efforts to ensure their family members can read and complete the al-Qur'an. This phenomenon shows that the community in Perhentian Island need sustained guidance such that the existing functionality can be strengthened through consolidation programmes specifically related to al-Qur'an studies. This can be implemented through Islamic department of Terengganu State government's programme. This is because the family must be provided with sufficient knowledge to fulfill its responsibilities of educating the family to master al-Qur'an as stated in Al-Bukhari (1998) and Fahrudin (2012).

\section{CONCLUSION}

This study has shown that family functionality of Perhentian Island residents was at good level in ensuring family member's ability to recite al-Qur'an. Parents of the respondents have played the appropriate role in ensuring their family members can master al-Qur'an. However, parents are not the only factor contributing to this family functionality in the island. This study also shows that their situation isolated by location from the infrastructure development which normally enjoyed by the mainland community did not influence them in expressing their functionality. Nevertheless, the islanders need assistance in mastering Quranic knowledge so that their existing functionality can be strengthened and able to produce their capable of recitation al-Qur'an and subsequently complete it. This role must be played by the authorities appropriately. The findings of this study will help stakeholders such as schools and government agencies to formulate programmes to ensure the family institution in the island is strengthened at all times and in the future.

Funding: This article resulted from research carried out using the University Research Grant/Geran Penyelidikan Universiti (GPU) Universiti Pendidikan Sultan Idris.

Competing Interests: The authors declare that they have no competing interests

Acknowledgement: This research was carried out under supervision of the Research

Management and Innovation Centre (RMIC) UPSI under the research code 2017-0290-10701.

\section{REFERENCES}

Adi Fahrudin. (2014). Family functionality: Concepts and indicators of measurement in research. Paper presented at the Working Paper of the 2014 National Seminar on Family Integrity, Faculty Psychology and Education, Universiti Malaysia Sabah (11 Dec 2014).

Al-Bukhari, M. B. I. 1. (1998). Sahih Bukhari. Mohamed Fo'ad Abd. Al-Baqi (Then.). Beirut: Dar Touq Al-Najat.

Al-Tabarani, S. B. A. (1995). The path of Awwad Allah (as). Al-Jam Al-Awsat. Cairo: Dar Al-Haramain. 
Amran, H., Fatimah, Y., \& Khadijah, A. (2012). The relationship between parental skill and family functioning to the psychological wellbeing of parents and children. Paper presented at the International Conference on Humanity, History and Society IPEDR. Singapore; IACSIT Press.

Azarudin, A., Mat, A. C., Nazuki, A., \& Yaakub, M. (2011). The level of Al-Quran reading among students at UITM Terengganu. AJTLHE: ASEAN Journal of Teaching and Learning in Higher Education, 3(2), 83-100.

Fahrudin, A. (2012). Family functioning: Concepts and measurement indicators in research. Sosio Informa, 17(2), 75-81.

Hofstede, G. (1994). Culture and organizations: Intercultural cooperation and its importance for survival. Software of the mind. London: Harper Collins.

Inkeles, A., \& Smith, D. H. (1974). On becoming modern. London: Heineman.

Ishak-Mad, S. (2004). Self -concept and academic achievement of adolescents: Seeing the extent to which parental leadership styles as moderators. Journal of Technology, $40(\mathrm{E}), 33-44$.

Misnan, J. (2005). The level of mastery of the Qur'an among secondary school students in Perak. Dlm. Paper presented at the Proceedings of the 4th Islamic Education Discourse Series. Bangi: Faculty of Education, Universiti Kebangsaan Malaysia.

Mohd Faisal, M., Zawawi, I., \& Rahimi, M. S. (2008). Quranic literacy: Challenges and realities in Islamic education in schools. Journal of Educational Problems, 31(1), 241- 253.

Mohd, Y., Zulkifli, b. H. M. Y., \& Saidi, B. M. (2007). The ability to read the Qur'an among form four students in selected secondary schools in the state of Terengganu. Journal of al-Bayan, 6, 53-85.

Nanthakumar, L., \& Thirunaukarasu, S. (2005). Dynamic poverty patterns of island and coastal communities: A case study of Pulau Perhentian. Journal of Southeast Asian Studies, 10, 151-169.

Rohaty, M. M. (2003). Preschool education: Quality challenges (Premier Lecture). Bangi: Malindo Publishing.

Salina, B. S. d. (2006). Perceptions of form 2 students of Taman Universiti 1 National Secondary School on learning Tilawah al-Quran. Skudai: Malaysia: UTM.

Simon, W. (1996). Postmodern sexualities. London: Routledge.

Siti-Fatimah, S. (2005). The need for al-Qur'an reading skills course in IPT: A study at UiTM Shah Alam. Journal Center for Islamic Thought and Understanding, 1(2), 133-152.

Triandis, H. C. (1973). Subjective culture and economic development. International Journal of Psychology, 8(3), 163-180. Available at: https://doi.org/10.1080/00207597308247073.

Yahaya, I. (2006). Tioman island of Malay Community: Issues and challenges in the context of tourism development. Journal of Malay, 2, 152-167.

Zurina, M., \& Hukil, S. (2007). The relationship of community values \& development: One analysis. Journal of General Studies, 8 , $77-79$.

Views and opinions expressed in this article are the views and opinions of the author(s), International Journal of Asian Social Science shall not be responsible or answerable for any loss, damage or liability etc. caused in relation to/arising out of the use of the content. 